\title{
PENGORGANISASIAN GERAKAN SOSIAL BERBASIS PETISI ONLINE (STUDI KASUS: CHANGE.ORG INDONESIAN CHAPTER)
}

\author{
Muhammad Dedy \\ Departemen Sosiologi Universitas Indonesia \\ Muhammaddedy21@gmail.com
}

\begin{abstract}
The purpose of this research is to clarify the role of online organization media, change. org, as a form of support for protesting that claimed virtual collective. Previous research explains that the online media has been used for political campaigns, as well as a tool to express ideas openly, but still organized online and offline elementary. Specifically, this research wanted to show that change.org can be a tool for protest to claim a collective complaint based virtual form in the form of an online petition. Such cases tend to be higher in urban communities because it is relatively more active in terms of Internet usage so that the use of media such as online petitions can be a tool to pass up a protest which will be expressed as a collective complaint. Online media is considered to be an appropriate tool in collecting petition claims because everyone will be able to access the Internet as well as determine the attitude to an event that occurred. By using qualitative research methods, this research interview the informant involved in the manufacturer's online petition change.org online petition and the petitioners online. Conclusion Change.org is a vital tool for spreading ideas and at the same time being an identity for movement.
\end{abstract}

\begin{abstract}
Abstrak
Penelitian ini bertujuan untuk menjelaskan peran media online change.org sebagai bentuk pengorganisasian dukungan gunamelakukan protes yang terklaim kolektif secara virtual. Penelitian sebelumnya menjelaskan bahwa media telah digunakan untuk alat kampanye politik serta untuk menyampaikan gagasan secara terbuka, namun masih terorganisasi secara online dan ofline yang elementer. Secara khusus, penelitian ini ingin menunjukkan bahwa change.org dapat menjadi alat untuk melakukan protes yang dapat menjadi kekuatan untuk mengklaim suatu keluhan secara kolektif berbasis virtual berupa petisi dalam bentuk online. Kasus semacam ini cenderung tinggi di masyarakat perkotaan karena relatif lebih aktif dalam hal penggunaan internet sehingga penggunaan media berupa petisi secara online dapat menjadi alat untuk melalukan protes yang akan bisa dinyatakan sebagai keluhan kolektif. Media online dianggap dapat menjadi alat yang tepat dalam mengumpulkan klaim petisi sebab semua orang akan dapat mengakses internet sekaligus menentukan sikap terhadap suatu peristiwa yang terjadi. Dengan menggunakan metode penelitian kualitiatif, penelitian ini mewawancarai informan yang terlibat dalam petisi online change. org yakni pembuat petisi online dan penandatangan petisi online.KesimpulannyaChange. org merupakanalat vital untuk menyebarkan ide dan sekaligus menjadi identitas guna melakukan gerakan.
\end{abstract}

Keywords: Online Media, Petition, Social Movement 


\section{PENDAHULUAN}

Pada tahun 2013, Indonesia tercatat sebagai salah satu negara dengan jumlah pengguna internet tertinggi di dunia yaitu sebesar 28 persen, dari jumlah pengguna internet yang mencapai 82 juta dari 250 juta penduduk Indonesia yang aktif menggunakan internet (http://www. statista.com/topics/2431/internet-usage-inindonesia/ diakses pada 4 Maret 2016 pukul 22.15 WIB. Dilihat dari pemanfaatannya, internet digunakan untuk berbagai macam hal, mulai dari browsing data, download aplikasi, hingga bisa menjadi alat untuk mengekspresikan diri secara virtual.

Saat ini internet juga menjadi salah satu media untuk melakukan protes. Salah satu protes berbasisinternetyang dapatdilihatsaat ini adalah munculnya petisi online melalui website change.org. Change.org bekerja sebagai wadah untuk menyatukan klaim, dengan cara mengumpulkan dukungan yang sebanyak-banyaknya. Dalam prosesnya, cara kerja dari petisi online ini adalah dimulai dengan membuat suatu petisi online di laman website tersebut (www.change.org). Lalu disebar luas melalui jagat maya dan semua orang berhak untuk berpartisipasi dengan cara menandatangani petisi tersebut.

Hal ini menjadi siklus berulang dimulai dari penyebaran ke seluruh jaringan virtual yang dimiliki oleh orang-orang yang telah menandatangani petisi tersebut. Setiap petisi yang ditandatangani, akan masuk kedalam e-mail dari objek yang menjadi sasaran petisi. Sehingga semakin banyak orang yang menandatangani petisi, maka akan semakin banyak pula pesan yang akan masuk ke dalam email objek sasaran petisi tersebut. Hal ini tentu akan menimbulkan suatu dampak berupa tanggung jawab bagi penerima e-mail untuk menghargai atau bahkan menuruti permintaan orang-orang yang menandatangani petisi.

Mengapa proses tersebut bisa terjadi? dan apakah setiap petisi tersebut selalu ditanggapi oleh sasaran petisi? Lalu bagaimana bentuk pengorganisasian protes yang dilakukan oleh pihak yang membuat maupun menandatangani petisi tersebut dalam hal mencapai tujuan protes yang mereka lakukan?Tulisan ini ingin melihat bentukpengorganisasian protesyang berbasis petisi virtual dalam mempengaruhi suatu kasus atau kebijakan yang akan atau telah dibuat oleh pengambil kebijakan tersebut.

Studi-studi sebelumnya menunjukkan setidaknya terdapat dua kelompok argumen mengenai eksistensi media dalam hal menggerakkan opini masyarakat serta menciptakan protes. Pertamaadalah berbagai studi yang coba memaparkan media sebagai strategi politik oleh para pemilik media dan pelaku ataupun aktor-aktor politik (Imran, 2009. Wihbey, 2015). Mereka mengatakan bahwa media cetak maupun online pada saat ini memiliki pengaruh yang sangat besar dalam mempengaruhi opini masyarakat, sekaligus menciptakan suatu frame dalam mindset dalam tataran level induvidu, bahkan masyarakat. Dalam tulisannya, mereka juga mengatakan bahwa media-media yang seringkali diakses oleh setiap individu akan dapat memberikan suatu sugesti yang kemudian memberikan pengaruh untuk menentukan sikap yang akan diambil dalam menentukan suatu tindakan yang dilakukan. Hal ini tidak terlepas dari tingginya tingkat akses informasi, baik cetak maupun internet yang dilakukan oleh seseorang pada saat ini. Bahkan, di Indonesia maupun di dunia internasional, media digunakan sebagai alat untuk menciptakan suatu pencitraan politik, sekaligus alat kampanye dalam dunia perpolitikan. Sebagai contoh ketika masa-masa pemilu Amerika Serikat pada tahun 2008 para calon kandidat yang maju mencalonkan diri pada saat itu menggunakan internet sebagai salah satu media kampanye yang memberikan dampak signifikan dalam meningkatkan elektabilitas sekaligus popularitasnya. Namun, peenulis memberikan kritk bahwa studi ini hanya memaparkan media sebagai suatu alat untuk menggerakkan opini masyarakat, belum dapat mewadahi opini ataupun argumen masyarakat yang ingin bersikap.

Argumen kedua adalah studi-studi yang berpendapat bahwa pada kenyataannya, 
jumlah penduduk yang ada di dunia saat ini di dominasi oleh para kaum muda yang lebih tertarik untuk mencari informasi dari media (baik cetak maupun online) sebagai sumber terpercaya, sekaligus dianggap sebagai media yang tidak hanya digunakan untuk berkumpul, namun digunakan sebagai metode dalam menuangkan ide dan pikirannya (Juliastuti, 20o6; Owen, 2008). Para kaum muda cenderung aktif dalam hal mengakses internet. Kemudian menjadikan internet sebagai sarana untuk menjalankan kepentingan-kepentingan yang mereka butuhkan. Dalam penggambarannya, para kaum muda menggunakan media untuk menyampaikan opini terkait apa yang mereka gagas, sekaligus mengajak orang-orang untuk sepakat dengan gagasan tersebut.

Banyak tulisan-tulisan yang dihasilkan oleh para mahasiswa di Indonesia, terutama dalam konteks era awal reformasi tahun 1998 yang berisi tentang ide-ide dan gagasan mereka dalam berbagai bidang, sekaligus menggunakan media sebagai alat untuk saling bertukar informasi antar satu sama lain. Bagitupun konteksnya dengan pemudapemuda diluar negeri. Tidak sedikit pemudapemuda Amerika Serikat pada masa pemilu presiden 2008 yang terafiliasi dengan partai politik menjadikan media, khususnya media online sebagai alat untuk mempengaruhi orang-orang dan kerabat yang ada disekitarnya. Ditambah lagi, pada konteks saat itu, orang-orang akan cenderung lebih percaya dengan apa yang mereka peroleh dari kerabat sekitarnya karena dianggap sebagai jaringan pribadi yang mereka miliki (Owen, 2008). Namun, analisis semacam ini hanya menjelaskan bahwa bentuk gerakan-gerakan tersebut masih terbatas dan hanya dilakukan oleh orang-orang atau kelompok tertentu, serta masih dianggap elementer sebab hanya berbentuk tulisan ataupun argumen yang hanya disampaikan melalui akun media sosial pribadi masing-masing. Oleh sebab itu, umumnya yang mereka sampaikan pada akun media sosial tersebut hanya didukung sebatas oleh orang-orang di lingkungan sekitarnya, namun kurang didukung oleh pihak lain terutama pihak-pihak yang berasal dari luar kelompok tersebut.

Pertanyaan yang kemudian muncul menurut penulis saat ini adalah, apakah hal-hal yang dipaparkan diatas masih sepenuhnya relevan dengan konteks yang ada saat ini, khususnya pada masyarakat urban? Dalam prosesnya, media, khususnya media online menjadi semakin berkembang. Akan tetapi dalam konteksnya kini, khususnya pada masyarakat urban, terdapat suatu kebaruan dalam media online untuk kembali menampung opini masyarakat, dan media online ternyata juga dapat menjadi suatu gerakan aksi yang meskipun berbasis virtual, namun ternyata dapat memberikan dampak yang cukup signifikan, khususnya dalam mempengaruhi suatu kebijakan yang akan atau yang telah dibuat.

Penulis menemukan bahwa pada masyarakat urban, media online telah berkembang pada kemampuan untuk menciptakan suatu protes berbasis virtual hingga membentuk suatu pengorgansiasian yang mampu menjadi landasan untuk melakukan protes secara langsung. Pengorganisasian ini dilakukan dengan menjadikan petisi online sebagai alasan untuk membentuk suatu gerakan protes bersama, lalu menggunakan hasil petisi online sebagai landasan awal untuk melakukan gerakan yang lebih nyata dalam melakukan suatu protes.

Change.org adalah salah satu bentuk dari alat untuk melakukan protes virtual tersebut. Change.org dapat menampung aspirasi masyarakat yang ingin bersikap terhadap suatu kasus yang terjadi, kemudian dapat untuk membuat para pembuat kebijakan mengambil keputusan yang mempertimbangkan bagaimana respon masyarakat melalui website tersebut. Hal ini disebabkan oleh pengaruh media yang sudah sangat besar dalam konteks masyarakat urban. Media dapat menjadi representasi masyarakat, sekaligus alat kontrol untuk pembuat kebijakan dan merespon kebijakan tersebut. Media merupakan salah satu corong informasi yang bisa dimanfaatkan masyarakat untuk memperoleh informasi, sekaligus merespon fenomena yang terjadi. 


\section{METODE}

Dalam penulisan artikel ini, metode penelitian akan menjelaskan pengorganisasian protes melalui 2 (dua) level. Pertama yakni dalam hal kesamaan motif dan kedua pengorganisasian protes menggunakan konsep Transmedia Mobilization yang dikemukakan oleh Sasha Costanza-Chock (2013). Metode penelitian yang digunakan adalah metode kualitiatif berupa pengumpulan data dengan melakukan wawancara mendalam kepada 12 (dua belas) informan yang terdiri dari pembuat petisi dan penandatangan petisi.Wawancarakepadainformandilakukan dalam rentang waktu bulan Februari hingga Mei 2016. Metode penelitian ini dugunakan untuk mencari beberapa aspek yang dimiliki oleh informan maupun topik penelitian yang dilakukan seperti latar belakang, penyebab dari terjadinya fenomena yang diteliti, serta dampak-dampak yang ditimbulkan terhadap kehidupan sosial informan penelitian (Neuman, 2006). Penelitian ini adalah studi kasus atas petisi online change.org yang ingin memberikan gambaran bagaimana proses media onlinesebagai alat untuk melakukan protes berbasis virtual sekaligus pengorganisasiannya khususnya bagi para orang-orang yang terlibat dan menandatangani petisi tersebut.

Dalam penelitian ini, terdapat 4 (empat) studi kasus analisis petisi yang dibuat pada change.org. Petisi tersebut berupa petisi Dukung KPU (dibuat atas nama BEM UI tahun 2014), Pencabutan SK Drop Out Ketua BEM UNJ Roni Setiawan (dibuat atas nama Aliansi Mahasiswa UNJ bersatu tahun 2016), Pengusutan kasus pembunuhan berencana salim kancil (dibuat atas nama Tim Kerja Perempuan dan Tambang tahun 2015) dan terakhir adalah petisi tuntutan pembekuan PSSI (dibuat atas nama Pecinta Sepak Bola Indonesia tahun 2015).

Unit analisa dalam penelitian ini adalah individu, yakni penduduk perkotaan yang pernah terlibat dalam petisi online di change.org. Informan dalam penelitian ini terbagi dalam beberapa aspek, seperti pembuat petisi dan penandatangan petisi. Penentuan aspek-aspek ini menjadi penting mengingat fenomena yang terjadi dalam terbentuknya petisi online tersebut terjadi untuk merespon dari suatu tindakan atau peristiwa yang dianggap melibatkan banyak pihak. Hal ini juga menjadi penting sebab petisi online yang muncul juga berkaitan dengan bentuk protes yang dilakukan oleh masyarakat. Status masyarakat perkotaan menjadi penting sebab masyakat perkotaan adalah orang-orang yang sangat sering mengakses internet.

Selain itu, penelitian ini juga mengunakan data-data sekunder berupa data-data yang bersumber dari internet serta tulisan-tulisan dan jurnal akademik. Hal ini bertujuan untuk memperkuat argumenargumen dalam penelitian dengan berkaca pada penelitian-penelitian sebelumnya.

\section{HASIL DAN PEMBAHASAN}

\section{Petisi Online Change.org Sebagai Alat Protes Virtual}

Protes yang dilakukan oleh masyarakat selalu berkembang, khususnya di masyarakat urban. Dalam artikel-artikel sebelumnya belum menyebutkan bahwa perkembangan protes yang dilakukan oleh masyarakat saat ini telah memasuki bentuk virtual melalui media-media online. Hal ini mengingat bahwa perkotaan tidak terlepas dari konteks masyarakat urban yang begitu akrab dengan perkembangan teknologi.

Oleh sebab itu, penelitian ini ingin melihat peran media online sebagai bentuk protes virtual yang dilakukan oleh masyarakat dalam konteks masyarakat urban. Aksesibilitas internet yang mudah dan dimanapun menjadi salah satu faktor penting dalam terciptanya hal tersebut. Teknologi juga dapat mempermudah seseorang untuk bertemu dengan orang-orang yang memiliki pandangan yang beragam, lalu membentuk suatu perkumpulan berbasis virtual tanpa harus mengadakan pertemuan secara langsung terlebih dahulu. Media online dapat menjadi suatu alat untuk menyatukan aspirasi-aspirasi masyarakat yang ingin memberikan opini terhadap suatu fenomena apapun, yang tidak terbatas oleh ruang dan waktu. 
Dalam prosesnya, bentuk-bentuk protes yang dilakukan oleh masyarakat terhadap suatu fenomena yang dianggap janggal memiliki berbagai cara yang beragam. Pada awalnya, seseorang ataupun kelompok akan menyampaikan hal tersebut secara langsung, baik secara individu ataupun kelompok melalui demonstrasi ataupun unjuk rasa (Crozat, 1998; McCarthy dan McPhail, 1998). Menurut Putnam (dalam Ear dan Kimport 2009), protes merupakan suatu bentuk standard procedure dalam kehidupan sehari-hari terkait dengan gerakan yang tradisional. Seseorang atau pun kelompok dapat memberikan reaksi yang beragam terhadap fenomena yang terjadi apabila fenomena tersebut dianggap sebagai suatu hal yang tidak wajar, dan diangap merugikan masyarakat (Ear dan Kimport, 2009: 5).

Turner (dalam Opp 2009) mengatakan bahwa protes adalah adalah bentuk ekspresi keluhan terhadap ketidakadilan. Para aktor protes umumnya tidak dapat memperbaiki kondisi langsung dengan usaha sendiri, sehingga aktor protes akan melakukan tindakan lebih lanjut berupa provokasi yang bersifat untuk memperbaiki. (Opp, 2009: 35).

Lalu, Meyer dan Tarrow juga mengatakan bahwa bentuk-bentuk protes tradisional ini kemudian dilembagakan dalam bentuk petisi (dalam Ear dan Kimport, 2009) yang bertujuan untuk mendapatkan suatu klaim yang lebih tersentralisasi. Hal ini menjadi penting untuk semakin menguatkan argumen agar dapat memberikan reaksi yang lebih kuat dalam menyikapi suatu kasus yang terjadi. Kelompok masyarakat yang protes akan menyatukan pendapat dengan mereka yang sepakat melakukan protes lalu kemudian menyatakan sikap untuk melakukan suatu tindakan.

Media online semakin berkembang dan bertransformasi sampai kepada level untuk melakukan protes berbasis virtual untuk melakukan protes terhadap suatu fenomena. Mulai dari menuangkan opiniopini melalui tulisan bebas dalam websitewebsite pribadi ataupun media sosial yang dapat diakses oleh orang banyak seperti facebook, twitter, dan lain sebagainya. Akan tetapi, media-media tersebut dianggap kurang memberikan dampak yang signifikan untuk melakukan protes secara virtual. Oleh sebab itu, muncul change.org sebagai wadah yang dianggap dapat untuk memberikan dampak yang siginifikan dalam menyatakan sikap untuk merespon suatu fenomena yang dianggap janggal, dan tidak seharusnya terjadi. Masyarakat akan menyatakan sikap dengan cara menandatangani secara virtual suatu petisi yang dibuat oleh seseorang yang merupakan bagian dari ketidaksetujuan atas terjadinya fenomena tersebut. Change. org juga memberikan kebebasan kepada siapapun untuk membuat suatu petisi online yang ingin memberikan suatu respon terhadap suatu fenomena yang terjadi. Dengan semakin banyaknya orang yang menandatangani secara digital pada petisi tersebut, maka argumen untuk melakukan suatu protes dan penolakan dianggap akan semakin kuat sekaligus dianggap sebagai representasi dari sekelompok orang ataupun masyarakat tertentu.

Change.org juga menampilkan suatu laporan tahunan yang dikirim ke semua email para penandatanganan petisi dalam bentuk info grafis (https://www.change. org/id/tentang/infografis2015?alert_ id=PIRHUyjcbC_QrDKjblq\%2BmCF2 sIcg 7SJfa 6vR\%2 FKDU66QIyGi1YNcIu U\%3D\&utm_campaign=479786\&utm_ medium=email\&utm_source=action_alert diakses pada 20 April 2016 pukul 22.30 WIB). Pada tahun 2015, info grafis yang dibuat oleh change.org memberikan beberapa informasi yang cukup populer sepertikumpulankumpulan petisi yang paling banyak ditandatangani. Lalu pihak pengambil keputusan yang kemudian merespon petisi tersebut. Hingga petisi yang kemudian berhasil mengubah suatu kebijakan yang sebelumnya dianggap merugikan yang kemudian direspon dalam bentuk petisi di change.org. Sebagai contoh terdapat beberapa kemenangan selama tahun 2015 berkat adanya petisi di change.org yaang diantaranya adalah pilkada langsung yang berisi tentang tuntutan penghapusan wacana 
bahwa pilkada akan dilakukan secara tidak langsung. Kemudian tentang petisi Jaminan hari tua yakni saat Gilang Mahardika yang tidak dapat mengambil dana pensiunnya karena adaya kebijakan baru, lalu di respon oleh Menaker hingga kebijakan pun berubah.

\section{Motif Tindakan Melakukan Protes}

Aktor protes akan mengekspresikan ketidakadilan dengan berbagai cara, baik itu dengan bentuk keluhan, tidakan, atau bahkan gerakan bersama dengan cara mengajak pihak lain yang juga dianggap merasakan ketidakadilan tersebut. Hal ini tentunya memberikan gambaran bahwa ada banyak motif yang menyebabkan terjadinya protes tersebut. Penelitian menemukan dua garis besar yang menjadi motif utama dalam melakukan protes, yakni, pertama, protes muncul disebabkan atas dasar ketidakadilan yang dirasakan dan/atau rasa bosan untuk tidak melakukan apapun disaat tahu bahwa ada suatu kondisi yang dianggap tidak benar.

Kedua, protes dilakukan atas dasar kecintaan terhadap situasi sehingga aktor protes menginginkan terciptanya suatu situasi yang lebih baik, dan menguntungkan berbagai pihak. Selain itu, faktor ketidaknyamanan dengan situasi yang ada juga mampu menjadikan penyebab dari munculnya suatu protes.

Pertama, banyak orang yang mengetahui kondisiada pada saat itu merupakan suatu hal yang salah. Namun semuanya enggan untuk berkomentar, atau lebih tepatnya enggan memulai untuk melakukan suatu perubahan. Temuan ini dapat dilihat dari Informan $P$ (wawancara pada 28 April 2016). Ia merasa bahwa perlu untuk melakukan protes karena selama ini bosan menunggu orang lain untuk melakukan perubahan. Pada saat itu, ia berinisiatif untuk melakukan suatu protes terhadap suatu hal yang dianggap sudah dianggapsebagaitindakanyangmenyimpang, hingga mencari teman dan pihak-pihak lain di lingkungannya yang dianggap juga peduli dengan kasus tersebut untuk memulai suatu protes dengan cara menyampaikan keluhan sekaligus tuntutannya melaui sebuah petisi online.

Informan $\mathrm{P}$ mencontohkan tentang kasus pembekuan PSSI yang pada saat itu dianggap sudah tidak menjalankan fungsi dan perannya sebagai badan pengurus sepak bola nasional yang profesional. Ia merupakan salah satu penikmat dan pecinta olahraga sepakbola. Selain itu juga sebelumnya ia pernah bekerja sebagai jurnalis berita tentang sepakbola pada salah satu media cetak nasional. Hal ini yang menyebabkan ia begitu banyak tahu tentang perkembangan dunia sepakbola, baik nasional maupun internasional serta memiliki orang-orang di lingkungan sekitarnya yang juga paham akan permasalahan yang dialami oleh persepakbolaan nasional.

Diawali dengan terjadinya kasus sepak bola gajah yang terjadi pada liga sepakbola nasional, ia merasa bahwa permasalahan ini adalahpuncak dari ketidakprofesionalan PSSI sebagai badan pengurus sepakbola nasional dalam menjalankan fungsi dan perannya. Sepakbola gajah terjadi antara tim PSS Sleman Vs PSIS Semarang yang terjadi pada hari minggu (26/10/2014). Kedua tim samasama mencetak gol bunuh diri ke gawang masing-masing dengan alasan enggan untuk bertemu dengan tim Pusam Borneo FC karena dianggap sebagai lawan yang cukup kuat. Terdapat total 5 (lima) gol bunuh diri yang dicetak oleh kedua tim, masing-masing 2 gol untuk PSS Sleman dan 3 gol untuk PSIS Semarang (http://bola.liputan6.com/ $\mathrm{read} / 2125958 /$ sepak-bola-gajah-pss-vs-psisdisorot-media-internasional Diakses pada 1 Juni 2016 Pukul oo.05 WIB).

Ia bersama dengan temannya memutuskan untuk melakukan suatu gerakan protes kepada Menpora RI untuk segera melakukan intervensi kepada PSSI guna melakukan perubahan di tubuh PSSI. Mereka beranggapan bahwa sepakbola adalah olahraga yang begitu populer di masyarakat, sehingga amat sangat disayangkan apabila kompetisidanligasepakbolanasionalberjalan dengan buruk, dan bahkan terjadi suatu kecurangan dan sekaligus penyimpangan 
didalamnya. Salah satu tuntutan dalam protesnya adalah membekukan PSSI dengan tujuan untuk memperbaiki dan merestrukturisasi kepengurusan PSSI guna mampu memperbaiki kinerja PSSI sebagai badan pengurus sepakbola nasional.

Kedua, protes muncul atas dasar kecintaannya terhadap sesuatu hal sehingga ia menuntut untuk tidak dicederai atau bahkan dirusak keberadaanya. Temuan ini didapat pada Informan A (diwawancarai pada tanggal 26 April 2016). Ia beranggapan bahwa umumnya protes semacam ini terjadi pada contoh permasalahan perebutan akan suatu sumberdaya. Ia melihat permasalahan ini dari sudut pandang yang mencoba untuk tidak memihak pada pihak yang sedang memperebutkan sumberdaya, melainkan untuk menjaga sumberdaya tersebut mulai dari cara dan juga proses mendapatkannya berjalan sesuai prosedur tanpa adanya kecurangan atau intervensi yang dapat merugikan dari salah satu pihak yang sedang bersaing.

Informan A menjelaskan pada contoh kasus pemilihan presiden (Pilpres) pada tahun 2014. Pada saat itu, ketika proses pencoblosan untuk mementukan presiden RI telah selesai dilaksanakan, kedua calon mengklaim bahwa mereka sama-sama memenangkan hasil dari pilpres tersebut. Begitu pula dengan para pendukungnya yang tidak sedikit menyatakan bahwa calon yang mereka dukung berhasil menjadi presiden terpilih. Mereka mengumumkan melalui media, yang salah satunya adalah televisi dengan memberikan deklarasi atas keberhasilan mereka dalam memenangkan hasil pilpres.

Padahal dalam proses yang diakui oleh negara, terdapat pihak KPU yang merupakan pemegang otoritas tertinggi dalam menentukan pemenang hasil pilpres 2014 . Informan A merasa khawatir akan adanya intervensi dan bahkan delegitimasi hasil pemilu presiden yang dilakukan oleh salah satu calon presiden untuk memenangkan dirinya sebab ia menyatakan menang melalui hasil quick count yang diadakan oleh beberapa lembaga survei nasional.
Informan A dan juga teman-temannya yang tergabung dalam suatu lembaga eksekutif kampus pada akhirnya berinisiatif untuk membuat suatu petisi yang bertujuan untuk mengawal dan mendukung KPU agar mereka tidak perlu merasa khawatir dan menekankan agar tidak perlu merasa terintervensi akan pengklaiman yang dilakukan oleh para calon presiden yang bertarung pada pemilu calon presiden tahun 2014. Ia dan teman-temannya menyatakan dukungan untuk tetap mendukung KPU dalam menjalankan fungsi dan wewenangnya selaku pihak yang berhak sekaligus sah dalam memutuskan pemenang dari pemilu presiden.InformanAmerasaperlumelakukan hal tersebut untuk melindungi pihak KPU, sekaligus memberikan respon kepada kedua belah pihak yang terlibat dalam perebutan kursi presiden pada pemilu presiden untuk tetap bersikap sebagaimana mestinya, yakni menunggu hasil penghitungan suara dan sekaligus menunggu hasil keputusan KPU terkait dengan pemenang hasil pemilu presiden yang telah diselenggarakan.

Dengan adanya pemaparan tersebut, dapat dikatakan bahwa protes merupakan suatu tindakan kolektif yang muncul karena dua hal utama. Pertama adanya suatu keluhan atas ketidakadilan yang dirasakan oleh aktor yang melakukan protes. Kondisi ini muncul bisa disebabkan oleh adanya kebijakan yang diambil oleh target aktor protes yang dianggap menyimpang sehingga para aktor tersebut merasa perlu melakukan protes untuk menuntut adanya suatu perubahan kondisi yang diharapkan dan sekaligus tidak merugikan masyarakat.

Kedua adalah adanya tujuan bersama yang disepakati oleh para aktor dalam melakukan gerakan protes untuk menuntut pemenuhan tujuan tersebut. Protes yang efektif harus diawali dengan persamaan tujuan dari para aktor protesnya. Hal ini menjadi penting guna memperkuat argumen sekaligus memberikan pressure kepada target untuk memenuhi tuntutan yang diajukan oleh aktor dalam melakukan gerakan protes tersebut. 


\section{Pengorganisasian Protes Virtual Pada Change.org Berdasarkan Transmedia Mobilization}

Dalam suatu protes, perlu dukungan yang banyak dari berbagai pihak guna menguatkan argumen dalam protes tersebut (Opp. 2009). Hal ini juga diperkuat dengan berbagai contoh kasus yang ada di Indonesia, salah satu contohnya adalah protes yang terjadi pada era reformasi tahun 1998. Massa dan dukungan yang berlimpah dalam melakukan suatu protes akan menjadikan itu suatu kekuatan guna menuntut kepada para pengambil kebijakan untuk mengambil tindakan yang sesuai dengan tuntutan para aktor protes.

Chontanza-Chock(2013:10) menjelaskan bahwa pengorgansiasian masyarakat yang berawal dari gerakan melalui media dapat menggunakan transmedia mobilization. Transmedia mobilization adalah gerakan sosial yang tersebar secara sistematis di beberapa platform media, lalu menciptakan sebuah gerakan sosial yang terdistribusi dan partisipatif dengan pola pengaturan yang jelas untuk memperkuat identitas dari gerakan tersebut.

Chontanza-Chock pun memberikan beberapa poin indikator dalam melakukan transmedia organzation yaitu: Satu, transmedia mobilization dapat menjadi suatu jaringan sosial yang digunakan untuk menyebarkan ide dan dan tujuan gerakan tersebut. Dua, transmedia mobilization dapat menciptakan suatu gerakan dan identitas bersama sebab semuanya sepakat dalam hal penggunaaan platform media yang digunakan. Tiga, diperlukan suatu kreasi serta kolaborasi dan dukungan antar aktor yang berbeda dalam gerakan sosial tersebut.Empat, diperlukan suatu pembagian fungsi dan peran yang jelas bagi para aktornya.Lima, terbuka dalam hal pertisipatif terutama bagi orang-orangorang dengan basis gerakan yang sama untuk bergabung dalam gerakan tersebut.

Protes umumnya pun terjadi karena adanya suatu hal yang terjadi atau akan terjadi yang tidak sesuai dengan apa yang diharapkan oleh orang lain. Semakin banyaknya dukungan dari berbagai pihak juga akan memberikan dampak yang kuat untuk melakukan protes dalam gerakan bersama yang lebih besar. Diperlukan suatu pengorganisasian yang tepat guna mengatur gerakan bersama tersebut agar orang-orang yang ada di dalamnya dapat bekerjasama dengan baik dan tidak merugikan satu sama lain. Sebagaimana yang telah dijelaskan oleh Chontanza-Chock di atas, tentu kelompok protes ini memiliki tujuan yang sama sehingga mau melakukan protes secara kolektif. Tujuan dan kepentingan yang sama ini kemudian menjadi identitas bagi gerakan ini untuk melakukan protes sehingga mampu memperkuat tuntutan yang ingin mereka ajukan. Indikator ini yang dikemukakan oleh Chontanza-Chock juga menjadikan protes online dalam gerakan melalui petisi online change.org sebagai landasan dasar bagi para aktor protes untuk melakukan gerakan.

Oleh sebab itu, pengorganisasian menjadi suatu hal yang diperlukan dalam gerakan bersama suatu protes. Unsur ataupun syarat yang diperlukan dalam suatu protes menurut Chontanza-Chock menjadi perlu untuk diperhatikan. Indikator-indikator yang dipaparkan oleh Chontanza-Chock dalam melakukan protes berdasarkan media juga sangat relevan dengan konteks change. org yang dijadikan sebagai objek media. Apabila pengorganisasian semacam ini telah mampu dijalankan, maka akan lebih mudah dalam menggerakan kelompok tersebut untuk melakukan gerakan bersama dalam suatu protes dan memberikan suatu tanda kepada para target gerakan protes tersebut untuk memenuhi tuntutan dari para aktor protesnya.

Dalamsuatugerakanprotesyangberbasis virtual menggunakan change.org, diperlukan suatu pengorganisasian guna menciptakan suatu gerakan protes yang dapat berjalan dengan efektif. Media menjadi alat vital dalam melakukan gerakan protes, terutama dalam hal menyebarluaskan ide dan tujuan dari gerakan tersebut. Aspek tersebut juga dapat ditemukan dalam pemanfaatan change. org sebagai gerakan dalam menyampaikan protes bagi para aktornya. Disamping itu , 


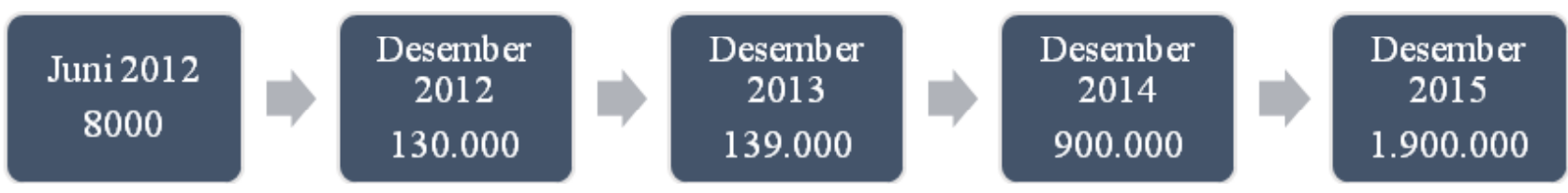

Grafik Penggunaan Change.org Tahun 2012-2016

Sumber : Change.org

penggunaan change.org sebagai petisi online juga tergolong tinggi dan semakin meningkat. Terhitung sejak tahun 2012, setidaknya grafik penggunaan petisi online change.org tidak pernah mengalami grafik penurunan. Peningkatan dalam penggunaan change.org sebagai gerakan protes virtual pun tergolong sangat signifikan.

\section{Grafik Penggunaan Change.org}

Angka pada grafik penggunaan change. orgtersebutmenunjukkanbahwapenggunaan change.org dianggap sebagai media sekaligus alat untuk memperkuat identitas yang efektif dalam melakukan suatu gerakan. Penggunaan change.org sebagai alat untuk merepresentasikan keluhan dan bentuk ketidaksetujuan akan situasi yang ada pada saat itu juga menjadi suatu gambaran bahwa change.org dianggap mampu mewadahi keluhan tersebut, sekaligus memiliki peluang untuk menciptakan perubahan sosial.

Seperti yang telah dijelaskan pada bagian metode penelitian, dalam penelitian ini terdapat 4 (empat) studi kaus analisis petisi yang dibuat pada change.org yakni petisi Dukung KPU, Pencabutan SK Drop Out Ketua BEM UNJ Ronny Setiawan, pengusutan kasus pembunuhan berencana salim kancil, dan terakhir adalah petisi tuntutan pembekuan PSSI.

Petisi Dukung KPU merupakan petisi yang dibuat oleh BEM UI sebagai suatu lembaga yang ingin bersikap mengenai riuhnya gesekan-gesekan yang terjadi antara dua pihak yang terlibat dalam proses pemilihan presiden sebab kedua belah pihak saling mengklaim bahwa mereka merupakan pemenang hasil pemungutan suara pada pemilihan presiden tahun 2014. Kedua belah pihak sama-sama mendeklarasikan kemenangan, selanjutnya salah satu calon kandidat presiden pada saat itu, yakni Prabowo Subianto melakukan klaim dan sekaligus berupaya untuk mengintimidasi dan mendelegitimasi hasil real count yang merupakan kewenangan dari KPU dengan mengatakan bahwa terdapat suatu kesalahan pada KPU jika muncul perbedaan antara hasil penghitungan resmi KPU dengan quick count lembaga survei miliknya (http://indonesiasatu. kompas.com/read/2014/o7/10/21082731/ jika.kpu.menangkan.prabowo.lembaga. survei.tuding.kpu.yang.salah. Diakses pada 29 Mei 2016 Pukul 15.05 WIB). Kondisi ini yang menyebabkan BEM UI merasa perlu mengambil sikap untuk mendukung independesi KPU dan siap untuk mendukung kinerja KPU agar tetap menjalankan tugas fungsi dan perannya.

Petisi kedua adalah petisi merupakan petisi terkait dengan gugatan pencabutan SK yang dikeluarkan rektor UNJ yang memutuskan untuk men-DO ketua BEM UNJ pada saat itu, yakni Ronny Setiawan yang dianggap melakukan pelanggaran dan penghinaan kepada kampus melalui media sosial. Rektor UNJ menilai Ronny telah melakukan tindak kejahatan berbasis Teknologi dan Penghasutan yang dapat mengganggu ketentraman lantaran sebelumnya terjadi banyak gerakan dan aksi protes yang dilakukan oleh para aktivis mahasiswa UNJ terkait dengan kebijakan rektor UNJ yang dianggap tidak tepat sasaran dan banyak merugikan kalangan mahasiswa UNJ. Dengan keluarnya SK rektor yang memutuskan bahwa Ronny Setiawan dinyatakan telah di DO dari kampus UNJ, maka banyak gerakan protes yang dilakukan oleh para mahasiswa dan organisasi kampus UNJ hingga membentuk suatu gerakan 
bersama dengan membentuk Aliansi Mahasiswa UNJ Bersatu. Mereka menyatakan bahwa keputusan Rektor merupakan keputusan yang tidak berkeadilan dan dianggap mematikan asas demokrasi.

Petisi ketiga berupa petisi penuntutan untukpengusutansecaratuntastentang kasus pembunuhan berencana yang terjadi pada seorang petani asal Lumajang, Salim Kancil. Salim Kancil dibunuh lantaran melakukan penolakan akan adanya penambangan pasir besi yang ada di desanya, Selok AwarAwar yang berkedok pariwisata yang justru berakibat rusaknya lingkungan desa pada Januari 2015. Salim dan temannya Tosan yang tergabung dalam Forum Komunikasi Masyarakat Peduli Desa Selok Awar-Awar dianggap menjadi provokator dalam penolakan aktivitas tambang tersebut. Pada 26 September 2016 Salim dan Tosan didatangi oleh sekelompok preman dan mengalami penganiayaan yang mengakibatkan Tosan harus dirawat di rumah sakit sebab menderita luka yang begitu parah. Sedangkan Salim dianiaya hingga meninggal dunia oleh para kelompok preman tersebut.

Berangkat dari permsalahan tersebut, dibentuklah suatu gerakan yang menuntut untukpengusutansecaratuntaspembunuhan terencana yang dialami oleh salim kancil yang dimediasi oleh Wahana Lingkungan Hidup (Walhi) yang merupakan bagian dari Tim Kerja Perempuan dan Tambang tidak hanya tentang kasus pengususutan secara tuntas terkait penganiayaan dan pembunuhan yang dialami oleh Salim dan Tosan, Walhi dan juga menuntut untuk diadakannya pengusutan secara tuntas terkait aktivitas penambangan pasir besi di wilayah Lumajang yang dianggap ilegal.

Petisi Keempat berupa petisi tentang tuntutan pembekuan terhadap Persatuan Sepakbola Seluruh Indonesia (PSSI) yang dianggap tidak menjalakankan fungsi dan perannya sebagai badan pengurus sepakbola nasional dengan baik dan juga profesional. Berawal dari laga sepakbola yang terjadi pada liga divisi utama (kasta kedua) sepak bola Indonesia lantaran adanya sepak bola gajah atau sepak bola yang pemainnya sengaja untuk mencetak gol ke gawang sendiri atau melakukan bunuh diri dan bertujuan untuk menderita kekalahan. Gerakan protes berbasis petisi online ini diinisiasi lantaran adanya rasa bosan dari para penikmat sepak bola yang melihat kondisi persepakbolaan nasional yang tidak kunjung membaik. Justru malah sebaliknya yakni terkelola dengan cara yang sangat buruk dan penuh dengan kecurangan. Oleh sebab itu, petisi ini digalang guna menuntut Menpora RI, Imam Nachrowi untuk mengambil tindakan intervensi terhadap PSSI dengan melakukan pembekuan sekaligus restrukturisasi di di tubuh PSSI guna menciptakan suatu badan pengelola sepakbola nasional yang profesional serta memiliki integritas.

Untuk memaparkan analisa kasus dari hasil temuan yang di dapat melalui wawancara informan, ada beberapa tahapan yang terjadi dalam penggunaan petisi online change.org dalam melakukan suatu gerakan protes hingga terciptanya suatu perubahan sosial.

Dalam analisa keempat contoh kasus yang terjadi dalam gerakan protes menggunakan media change.org, hal yang perlu dibahas pertama kali adalah motif dari adanya gerakan protes menggunakan media online tersebut. Untuk kasus pertama yaitu Dukung KPU yang dilakukan oleh BEM UI pada tahun 2014, motif melakukan gerakan protes adalah atas dasar kepedulian agar tidak terjadinya penyimpangan dalam proses atau prosedur dalam proses pemilihan presiden. Ini sesuai dengan pemaparan oleh Informan A selaku penanggung jawab atas gerakan Dukung KPU yang dilakukan oleh BEM UI

\section{Tahapan Penggunaan Petisi Online Change.org}

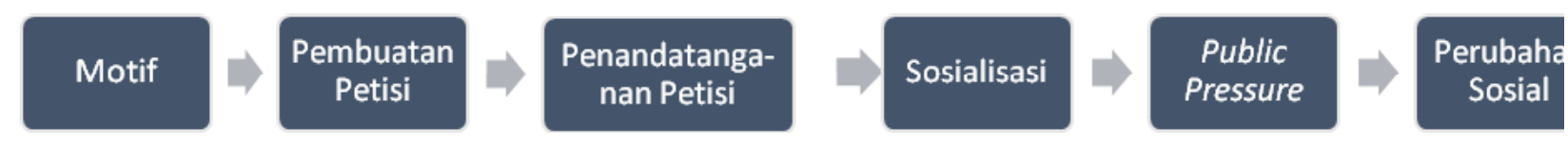


yang mengatakan:

“...sebenernya kita melakukan gerakan protes untuk mencegah adanya kecurangan dalam proses pemilu presiden. Makanya kita pengen nunjukin ke KPU melalui gerakan petisi ini, bahwa KPU ngga perlu takut terhadap intervensi dari pihak manapun. Sekaligus ngasih tau kalo BEM UI itu siap ngedukung KPU untuk menjaga independensinya." (Wawancara pada 26 April 2016).

Dalam kasus kedua yaitu tuntutan untuk pencabutan SK Rektor UNJ tentang keputusan DO terhadap ketua BEM UNJ saat itu yaitu Ronny Setiawan, motif dari gerakan protes ini dilakukan atas dasar ketidakadilan yang dirasakan oleh para aktor protes. Para Mahasiswa UNJ merasa bahwa Rektor mengeluarkan suatu kebijakan yang dianggap diluar batas keadilan, khususnya bagi para mahasiswa. Hal ini selaras dengan pendapat yang disampaikan oleh Informan S selaku Koordinator dari Gerakan Aliansi Mahasiswa UNJ Bersatu yakni :

“...Kita pada saat itu melihat bahwa ada suatu ketidakadilan yang dilakukan oleh Rektor. Makanya kita melakukan gerakan dan konsolidasi, sehingga memutuskan untuk membuat petisi secara online dalam menggalang dukungan. Soalnya kalo ini dibiarin, saya yakin banyak mahasiswa lain yang akan bernasib sama kayak Ronny." (Wawancara pada 10 Mei 2016).

Pada kasus ketiga tentang pembunuhan berencana yang terjadi pada kasus Salim Kancil pun memiliki motif yang sama dengan kasus kedua yaitu adanya suatu ketidakadilan dalam hal pengelolaan sumberdaya, hingga mengarah pada tindakan kriminal. Pembunuhan Salim Kancil yang menentang adanya penambangan pasir besi di daerahnya karena dianggap merugikan dan merusak ekosistem lingkungan. Hal ini diungkapkan oleh Informan M selaku perwakilan WALHI yang mengurus kasus pembunuhan Salim Kancil

“... Kasus ini kan udah menyebar ke tingkat nasional. Makanya, kita mau adanya keadilan dan penegakan hukum yang berjalan sesuai dengan aturan yang berlaku. Kita ngga pengen kasus ini tuh dibiarin gitu aja tanpa ada kejelasan. Sedangkan, pihak korban nyawa udah muncul dalam kasus ini." (Wawancara pada 17 Mei 2016).

Pada kasus keempat tentang tuntutan intervensi yang dilakukan Menpora pada PSSI berupa pembekuan PSSI dan sekaligus adanya restrukturisasi di tubuh PSSI berdasarkan motif kebosanan akan situasi yang telah menyimpang, namun tidak ada yang mau untuk memulai suatu gerakan protes. Ketidakprofesionalan PSSI dalam mengurus sepakbola nasional telah lama terlihat dan dirasakan, bahkan jauh sebelum adanya insiden sepakbola gajah di liga divisi utama PSSI. Akan tetapi, tidak ada satu pun pihak yang berani untuk memulai gerakan konkret untuk melakukan tuntutan dan perubahan tersebut. Hal ini diungkapkan oleh informan $\mathrm{P}$ selaku pembuat petisi sekaligus pihak pertama yang melakukan gerakan protes terhadap PSSI.

“... gua protes karena gua bosen aja untuk diem. Dan ngerasa kalo ini tuh udahjelas-jelas salah, tapingga adayang berani ngomong. Padahal sepakbola itu hiburan untuk semua kalangan. Sayang banget kalo dikelola buruk kaya gitu." (Wawancara pada 28 April 2016).

Indikator pertama dari ChontanzaChock (2013) adalah media dapat menjadi suatu jaringan sosial yang digunakan untuk menyebarkan ide dan tujuan gerakan tersebut. Dalam kasus petisi online, pembuat dan penandatangan menjadikan change.org menjadi suatu jaringan sosial yang menyebar secara viral di media online. Pembuat petisi dapat menjadikan change.org sebagai alat untuk menyebarkan ide dan tujuan dari adanya gerakan protes tersebut. Petisi dapat disebarkan secara online melalui seluruh akun media sosial pribadi masing-masing, seperti facebook, twitter, email, dan berbagai macam media sosial lainnya hingga petisi dapat tersebar dengan luas. Seluruh pembuat petisi dalam kasus ini melakukan hal yang 
sama dalam hal untuk menyebarkan ide dan tujuan dari gerakan mereka masing-masing.

Begitupun dengan penandatangan petisi, para penandatangan petisi juga melakukan hal yang sama karena menganggap bahwa ide dan gagasan tersebut harus di dukung oleh berbagai pihak, terutama pihak yang berkepentingan terhadap isu dan permasalahan yang dibawa dalam petisi tersebut. Hal ini diungkapkan oleh penandatangan petisi yaitu D, RY, P, dan $\mathrm{S}$ yang mana disaat setelah mereka menandatangani petisi tersebut, mereka akan coba selalu mensosialisasikan dan menyebarkan petisi yang di tandatangani kepada pihak lain, terutama orang-orang yang ada di lingkungan sekitar mereka.

'...gue biasanya juga nyebarin petisi yang udah gue tangdatanganin di change.org karena gue pengen orang lain juga tau kalo ada permasalahan yang butuh dukungan dan mesti segera diselesaikan." (Wawancara dengan informan RY pada 18 Mei 2016).

Indikatorkedua, transmediamobilization dapat menciptakan suatu gerakan dan identitas bersama sebab semuanya sepakat dalam hal penggunaan platform media yang digunakan. Hal ini menyebabkan keterkaitan dengan petisi yang dibuat pada change. org. Seluruh petisi yang dibuat dinamakan sesuai dengan nama yang mewakili individu ataupun kelompok yang tergabung dalam gerakan menggunakan petisi tersebut sebagai identitas baru sekaligus identitas bersama dari seluruh anggotanya.

Hal ini dapat dilihat pada petisi seperti Aliansi Mahasiswa UNJ Bersatu yang merupakangabungandariseluruhlembagakampus yang bersatu untuk menuntut pencabutan SK DO Rektor UNJ terhadap Ronny Setiawan, Pecinta Sepakbola Indonesia yang merupakan identitas bersamadariparaanggota kelompok gerakan untuk membekukan PSSI, serta Tim Kerja Perempuan dan Tambang (TKPT) yang merupakan gabungan dari LSM yang peduli atas pengusutan secara tuntas atas kasus pembunuhan berencana yang dialami oleh Salim Kancil.
Penandatangan petisi ini pun pada akhirnya secara tidak langsung terlibat dan merupakan bagiandari identitasbarugerakan petisi ini. Setiap petisi yang ditandatangani secara digital, maka itu akan menjadi penguat argumen dari tuntutan yang ingin disampaikan oleh para aktor gerakan kepada objek petisi tersebut.

Indikator ketiga adalah diperlukannya suatu kreasi serta kolaborasi dan dukungan antar aktor yang terlibat dalam gerakan tersebut. Tujuan dari dibentuknya identitas baru yang dibahas pada indikator kedua merupakan langkah awal untuk menciptakan suatu kreasi, kolaborasi serta dukungan antar aktoryang tergabung dalam gerakan tersebut. Hal ini bertujuan untuk menciptakan power yang lebih besar dalam melakukan gerakan, serta menjadi dasar utama dari penguatan tuntutan dalam gerakan tersebut. Mulai dari konsolidasi, penyamaan tujuan dan tuntutan bersama, serta penentuan cara dalam mencapai tujuan tersebut.

Setiap kelompok yang tergabung, tentu memiliki latarbelakang dan cara gerak yang berbeda antar satu sama lain. Tetapi ketika mereka telah berkolabolasi, dan sepakat dalam hal penggunaan mediayang digunakan untuk mempermudah tujuan mereka, hal tersebut membuktikan bahwa telah terciptanya suatu kolaborasi dan dukungan antar kelompok yang ada di dalamnya.

"ketika kita udah ngontak temen-temen ataupun LSM dari pihak lain yang sepakat untuk mendukung kasus Salim Kancil, kita pasti akan menentukan strategi dan gerak supaya kasus ini diusut dengan tuntas. Ya salah satunya dengan menggunakan media petisi change.org ini." (Wawancara dengan infroman M pada 17 Mei 2016).

Indikator keempat adalah pembagian fungsi dan peran yang jelas bagi para aktor yang ada di dalamnya. Penggunaan change. org sebagai media untuk melakukan gerakan, harus dibarengi dengan adanya penanggungjawab dalam setiap agenda gerakan yang dilakukan. Mulai dari harus adanya kordinator yang bertanggungjawab untuk mengatur segala pergerakan yang 
dilakukan oleh kelompok tersebut, penanggungjawab terhadap petisi yang dibuat, serta pihak yang bertanggungjawab sebagai pihak mediator dengan objek dari petisi tersebut.

Seluruh informan yang berkaitan dengan pembuatan petisi dalam penelitian ini merupakan informan yang bertanggungjawab sebagai koordiatoryang mengatur jalannya gerakan melalui petisi change.org. Koordinator bertanggungjawabsebagai pihak yang mengatur segala aktivitas dan gerakan kelompok agar dapat berjalan sesuai dengan apa yang telah disepakati bersama pada saat pembentukan dari kelompok gerakan ini.

"karena gue menginisiasi gerakan ini, gue ngontak temen-temen yang ngerasa bahwa ini permasalahan bersama dan sekaligus ngajak kumpul kalo ada yang mesti dibahas. Kita juga punya perannya masing-masing misalkan gue sebagai kordinator utama dan si $A$ sebagai koordiator yang media relasi. Gitu." (Wawancara dengan informan $P$ pada 28 April 2016).

Indikator kelima adalah harus keterbukaan dan sifat yang partisipatif terutama bagi orang-orang dengan basis gerakan yang sama untuk bergabung dalam gerakan tersebut. Pembuat petisi tidak akan mampu menggerakkan ataupun menguatkan argumen keluhannya apabila tidak terbuka dalam hal kesempatan kepada pihak yang ingin bergabung dalam gerakan tersebut. Akan tetapi, kelompok ini pun memiliki suatu syarat serta cara masing-masing sesuai dengankebutuhannyadalamhalmemberikan kesempatan kepada pihak baru yang ingin begabung dalam gerakan ini. Pihak pembuat petisi telah memiliki jaringan yang telah ada sebelumnya serta dianggap mampu diajak bekerja sama atau memberikan kesempatan kepada pihak baru yang ingin bergabung. Akan tetapi, pihak yang ingin bergabung dengan gerakan ini pun harus memiliki latarbelakang yang dianggap sesuai dengan tujuan dari gerakan yang telah ada. Hal ini sesuai dengan apa yang diungkapkan oleh informan S, A, M, dan P. "saatmelakukangerakanproteskemarin, pada dasarnya kita sangat terbuka kepada pihak manapun yang ingin bergabung dan menawarkan bantuan guna menyelesaikan permasalahan kasusnya. Tapi dari kita pun punya kriteria sendiri, dan harus melihat dulu latar bekalang pihak baru yang ingin bergabung. Karena kita ngga ingin pihak ini nantinya malah gerak yang ngga sejalan dengan kita." (Wawancara dengan S selaku koordinator utama dari Aliansi mahasiswa UNJ bersatu pada 17 Mei 2016).

Penandatangan petisi juga merasa perlu untuk berpartisipasi dalam hal menyebarkan dan terlibat dalam gerakan yang ditandatangani. Namun mereka pun memiliki kriteria tersendiri untuk melibatkan pihak lain dalam hal mengajakn ihak lain tersebut. Hal ini diungkapkan oleh informan E, U, RR, H, S, dan D.

"gue nyari pihak yang pasti mau dan ngedukung gerakan protes ini dulu. Ngga mungkin gue bakalan ngajak pihak yang dari awal aja udah ngga pro ama gue. Ntar yang ada malah ngerusak doang." (Wawancara dengan informan RR pada 19 Mei 2016).

Sehingga, dengan pemaparan lima indikator yang disampaikan oleh ChontanzaChock mengenai transmedia mobilizatuon pada analsisa kasus, petisi online change.org merupakan gerakan yang tidak hanya sekadar protes, namun telah tergolong dalam gerakan sosial (social movement). Gerakan yang berbasis petisi online change.org menuntut pihak-pihak yang terkait di dalamnya untuk melakukan suatu gerakan yang tidak hanya sekedar melakukan protes, akan tetapi di dalamnya terdapat pengorganisasian kelompok yang bertujuan untuk melakukan gerakan terstruktur serta memiliki identitas yang jelas sebagai satu kesatuan kelompok yang tergang dengan tujuan yang sama guna menuntut pihak yang dijadikan objek petisi untuk melakukan perubahan sosial ataupun perubahan kebijakan sesuai dengan tunttan para aktor gerakan sosialnya. 


\section{SIMPULAN}

Dariwaktukewaktu, gerakan sosial selalu mengalami perkembangan baik dari segi cara dan sifat gerakan yang dijalankan. Hal ini juga terjadi pada gerakan sosial yang kini telah mampu menggunakan media online sebagai basis gerakannya. Pengorganisasian gerakan sosial yang diawali dengan gerakan berbasis online seperti penggunaan petisi change.org merupakan suatu hal yang berbeda dengan gerakan sosial seperti pada umumnya sebab gerakan sosial ini memiliki semua unsur dalam konsep transmedia mobilization yang dikemukakan oleh Chontanza-Chock (2013).

Berdasarkan penjelasan dan analisa kasus yang telah dipaparkan diatas, gerakan berbasis petisi online menggunakan change. org saat dianalisa menggunakan konsep transmedia mobilizationyang dikemukakan oleh Chontanza-Chock merupakan suatu gerakan yang tidak hanya sekedar protes, melainkan sebagai termasuk dalam suatu gerakan sosial. Hal ini berdasarkan analisasi kasus berdasarkan indikatoryang dipaparkan oleh Chontanza-Chock dalam suatu gerakan transmedia mobilization. Change.org sebagai alat vital untuk menyebarkan ide dan sekaligus menjadi identitas guna melakukan gerakan.

Petisi yang di tandatangani secara digital pada change.org juga menjadi suatu landasan argumen untuk melakukan suatu gerakan yang sifatnya terstruktur dan sistematis sebab para aktor gerakan tersebut memiliki struktur gerakan yang jelas seperti koordinator dan kepala divisi yang dibentuk sesuai kebutuhan serta merancang tuntutan serta cara melakukan gerakan untuk mencapai tujuan bersama secara efektif. Gerakan sosial melalui change.org juga mampu mengorganisir para aktornya dengan pembagian tugas agar menjalankan fungsi dan peran yang disepakati, serta partisipatif dan terbuka dalam hal memberikan kesempatan kepada pihak manapun yang ingin bergabung selama memiliki tujuan yang sama dengan gerakan sosial tersebut.

Meskipun gerakan yang terbentuk dari adanya petisi online change.org sifatnya adalah temporar, namun para aktor yang ada didalamnya mampu diorganisasikan sesuai dengan kebutuhan dari gerakan sosial tersebut mulai dari koordinator utama hingga pembagian kepala-kepala yang bertanggung jawab memegang suatu bidang atau divisi tertentu yang ada dalam gerakan sosial tersebut. Hal inilah yang membuat gerakan sosial berbasis petisi online change. org menjadi suatu gerakan sosial yang tidak hanya mampu memberikan tekanan sosial kepada objek dari grakan petisi tersebut, akan tetapi juga mampu menciptakan suatu pengorganisasian tim yang mampu bekerja dengan baik guna mencapai hal yang disepakati sebagai tujuan bersama dalam gerakan sosial tersebut.

\section{DAFTAR PUSTAKA}

Chock, Sasha Costanza. (2013). Transmedia mobilization in the Popular Association of the Oaxacan Peoples, Los Angeles. The University of Chicago Press.

Earl, Jennifer. Katrina Kimport (2009). Movement Societies and Virtual Protest: Fan Activism and Other Nonpolitical Protest Online.University of California, Santa barbara.

Imran, Hasyim Ali (2009). political structure mediation by newspapers (Content Analysis Study On Newspaper In Capital City). Jurnal Studi Komunikasi Dan Media.

Jernigan, David H. Patricia A. Wright. (2006). Media Advocacy: Lesson from Community Experiences. Palgrave Macmillan Journals.

Juliastuti, Nuraini., Camelia Lesatri. (2006). Whatever I Want: media and youth in Indonesia before and after 1998. InterAsia Jurnal Cultural Studies, 7:1, 139143.

Kahne, Joseph. Ellen Middaugh. (2012). Virtualmediashapesyouth participation in politics. Stanfors Social Innovation Review. 
Kotze, Hendrik J (1986). Mass Media and Political Socialisation: A Sounth African Case Study. University of Stellenbosch in Sounth Africa.

Neuman, W. Lawrence. (2006). Social Research Methods: Qualitative and Quantitative Approaches. Toronto: Pearson.

Opp, Karl-Dieter. (2009). Theories of Political Protest and Social Movements. New York: Routledge.Owen, Diana (2008). Election Media and Youth Political Engagement. Journal of Social Science Education Volume 7/8, Number 2/1, 2008/o9, pp. 14-24.

Roscho, Bernard. (2004). Reviewed Public Opinion, the Press, and Public Policy. Oxford University Press.

West, Darrel M. (2005). Media and Public Policy. The American Political Science Review, Vol. 88, No. 4 (Dec., 2004), pp. 1007-1008.

Wihbey, John (2015). How does social media use influence political participation and civic engagement? A meta-analysis. Journalists Resourcee

\section{Website:}

http://bola.liputan6.com/read/2125958/ sepak-bola-gajah-pss-vs-psis-disorotmedia-internasional diakses pada 1 Juni 2016 Pukul 00.05 WIB

https://www.change.org/id/tentang/ infografis2015?alert_id=PIRHUyjcbC QrDKjblq\%2B mCF 2s Icg 7SJfa6v R\%2FKDU66QIyGi1YNcIuU\%3 D \&utm_campaign $=479786 \&$ utm medium=email\&utm_source=action alert diakses pada 20 April 2016 pukul 22.30 WIB

http://indonesiasatu.kompas.com/ $\mathrm{read} / 2014 / \mathrm{o} / 1 \mathrm{o} / 21082731 / \mathrm{jika} . \mathrm{kpu}$. menangkan.prabowo.lembaga.survei. tuding.kpu.yang.salah. diakses pada 29 Mei 2016 Pukul 15.05 WIB

http://www.statista.com/topics/2431/ internet-usage-in-indonesia/ diakses pada 4 Maret 2016 pukul 22.15 WIB 
